\title{
ADSORPTION OF HIGHRANGE WATER-REDUCING AGENTS ON SELECTED PORTLAND CEMENT PHASES AND RELATED MATERIALS
}

\section{R. Rossington}

School of Englneering New York State College of Ceramics Alfred University Alfred, NY 14802

\section{J. Struble*}

U.S. DEPARTMENT OF COMMERCE National Institute of Standards and Technology Center for Buliding Technology Galthersburg, MD 20899

* present address Department of Clvil Englneering University of Ililnols Urbana, IL 61801

U.S. DEPARTMENT OF COMMERCE Robert A. Mosbacher, Secretary NATIONAL INSTITUTE OF STANDARDS AND TECHNOLOGY

Raymond G. Kammer, Actlng Dlrector 
NATIONAL INSTITUTE OF STANDARDS \& TECHNOLOGY

Research Information Center

Gaithersburg, MD 20899 


\section{ADSORPTION OF HIGH-RANGE WATER-REDUCING AGENTS ON SELECTED PORTLAND CEMENT PHASES AND RELATED MATERIALS}

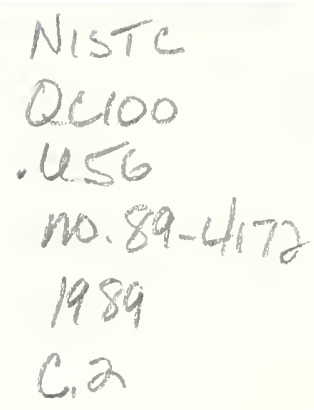

\section{R. Rossington}

School of Engineering

New York State College of Ceramles Alfred University

Alfred, NY 14802

\section{J. Struble*}

U.S. DEPARTMENT OF COMMERCE Natlonal Instltute of Standards and Technology Center for Bullaing Technology Galthersburg, MD 20899

*present address

Department of ClvII EnglneerIng Unlversity of IIIInols

Urbana, IL 61801

September 1989

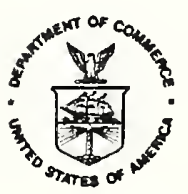

U.S. DEPARTMENT OF COMMERCE Robert A. Mosbacher, Secretary NATIONAL INSTITUTE OF STANDARDS AND TECHNOLOGY

Raymond G. Kammer, Actlng Director 

The quantities of high-range water-reducing agent (superplasticizer) adsorbed from their aqueous solutions by portland cement, tricalcium silicate, silica fume, wollastonite, and calcium silicate hydrate gel were determined using an ultraviolet spectrophotometer. The two superplasticizers (sulfonated melamine formaldehyde and sulfonated naphthalene formaldehyde) produced generally similar results. Wollastonite, a calcium silicate that does not react with water, produced no measurable adsorption of superplasticizer. The adsorption of superplasticizer by tricalcium silicate was similar to the adsorption by portland cement. From these results, it appears that superplasticizer is not adsorbed by anhydrous silica or anhydrous calcium silicate, but rather by calcium silicate hydrate gel. Additional studies are recommended for improving the understanding of the adsorption of superplasticizer by portland cement. 
Table of contents

Page

ABSTRACT . . . . . . . . . . . . . . . . . . . ii

1. INTRODUCTION .................. . . 1

2. EXPERIMENTAL APPROACH . . . . . . . . . . . 3

2.1 Materials . . . . . . . . . . . 3

2.2 Procedures. . . . . . . . . . . . . . 7

3. RESULTS AND DISCUSSION. . . . . . . . . . . . 10

4. CONCLUSIONS . . . . . . . . . . . . . . . 17

5. RECOMMENDED FUTURE WORK . . . . . . . . . . . . 17

ACKNOWLEDGEMENTS. . . . . . . . . . . . . . . . 18

REFERENCES. . . . . . . . . . . . . . . . . 19 
List of Tables

Page

Table 1. Surface Area Measurements . . . . . . . . . . . . 8 
Figure 1. Chemical structure of sulfonated melamine formaldehyde (a) and sulfonated naphthalene formaldehyde (b) (p. 212 , ref. [1]). . . . . . 2

Figure 2. X-ray diffraction pattern of synthesized

$\mathrm{C}-\mathrm{S}-\mathrm{H}$ (top) with JCPDS data for tobermorite (19-1364) (bottom) for comparison; the abscissa scale is ${ }^{\circ}(2 \theta)$ using $\mathrm{Cu} \mathrm{K} \alpha$ radiation. . . . . . . . . . . . . . 5

Figure 3. Scanning electron micrograph of synthesized $\mathrm{C}-\mathrm{S}-\mathrm{H}$.

Figure 4. Wavelength of maximum UV absorption versus concentration in aqueous solution for sulfonated naphthalene formaldehyde.

Figure 5. Wavelength of maximum UV absorption versus concentration in aqueous solution for sulfonated melamine formaldehyde . . . . . . .

Figure 6. Adsorption of sulfonated naphthalene formaldehyde in portland cement-water suspensions, water-to-cement ratio 0.5 by mass, 2 percent sulfonated naphthalene formaldehyde by mass of cement, comparing data from the previous study [7] (labeled SD \& LS) and from the present study (labeled DRR). . . . . . . . . . . . 12

Figure 7. Concentration of sulfonated naphthalene formaldehyde remaining in aqueous solution in portland cement-water suspensions, from adsorption data in Fig. 6. . . . . . . . . . 13

Figure 8. Adsorption of sulfonated melamine formaldehyde in various aqueous suspensions, water-to-solids ratio 0.5 by mass, 2 percent sulfonated melamine formaldehyde by mass of solid. . . . . . . . . . 14

Figure 9. Adsorption of sulfonated naphthalene formaldehyde in $\mathrm{C}-\mathrm{S}-\mathrm{H}$ suspension, waterto-solids ratio 1.5 by mass, 2 percent sulfonated naphthalene formaldehyde by mass of solid 


\section{INTRODUCTION}

One of the key options in modern concrete technology is the use of high range water-reducing agents (superplasticizers) to achieve very low water contents while maintaining necessary flow behavior. Superplasticizers allow reducing water contents in concrete by as much as 30 percent (p. 211, ref. [1]), reductions essential in the production both of high-strength concrete (utilizing normal techniques for mixing and placing) and ultrahigh strength concrete.

The two best-studied superplasticizers are sulfonated melamine formaldehyde (SMF) and sulfonated naphthalene formaldehyde (SNF). Each is an organic polymer; their chemical structures are shown in Fig. 1. The molecular weight of SMF is 30,000, while that of SNF is 500 to 2,500 [1].

Superplasticizers are dispersants, acting to prevent flocculation of cement particles by adsorbing on their surface and causing the particles to repel each other. The repulsion is generally thought to derive from electrostatic forces, though it has also been suggested that the repulsion is due in part to steric interactions (p. 197, ref. [2]). Evidence for electrostatic repulsion is provided by zeta potential studies: adsorption of superplasticizer from aqueous solution by cement, alite, tricalcium aluminate $\left(\mathrm{C}_{3} \mathrm{~A}^{1}\right)$, and calcium hydroxide $(\mathrm{CH})$ has been shown to cause large negative zeta potentials [3-6].

The dispersing action of superplasticizer does not always persist until the cement sets. A high proportion of superplasticized concrete shows slump loss (i.e., a decrease in fluidity prior to set). This slump loss may be appreciable and make the concrete unusable.

Another interesting aspect of superplasticizers is their enhanced effect with delayed addition. The slump is generally higher if the superplasticizer is added to concrete a few minutes after first mixing, rather than adding it with the mixing water.

Both slump loss and delayed addition are generally attributed to adsorption by, or reaction with, calcium aluminate sulfate hydrate (p. 219, ref. [1]) that forms during the initial hydration period. Therefore, laboratory studies have tended to focus on adsorption of superplasticizers by $C_{3} A$. From studies relating superplasticizer dosage to cement type, and from

${ }^{1}$ Certain chemical abbreviations, common in the cement literature, are used: $C$ for $\mathrm{CaO}, \mathrm{S}$ for $\mathrm{SiO}_{2}, \mathrm{~A}$ for $\mathrm{Al}_{2} \mathrm{O}_{3}, \mathrm{H}$ for $\mathrm{H}_{2} \mathrm{O}$. 


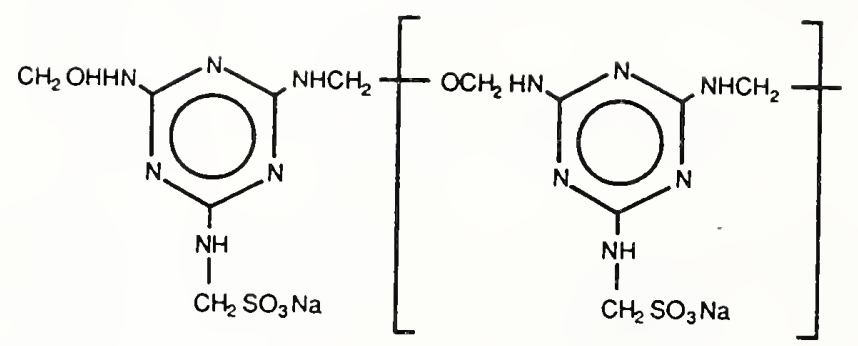

(a)

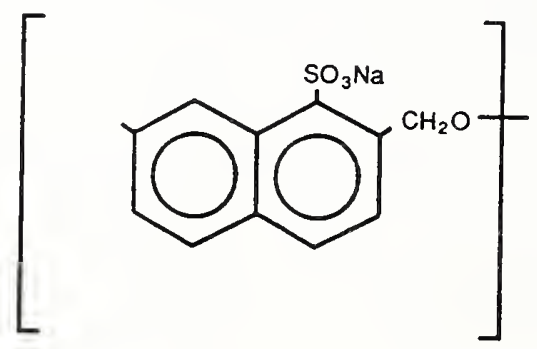

(b)

Figure 1. Chemical structure of sulfonated melamine formaldehyde (a) and sulfonated naphthalene formaldehyde (b) ( $p$. 212, ref. [1]). 
adsorption and zeta potential studies with individual cement phases, Ramachandran and Malhotra (p. 220, ref. [1]) concluded that adsorption is largely dependent on the $C_{3} A$ content of portland cement.

However, previous studies at the National Institute of standards and Technology (NIST) emphasized the importance of adsorption by calcium silicate hydrate (C-S-H) gel. These studies were carried out by $\mathrm{S}$. Diamond to determine the interactions between SNF and portland cement or cement plus silica fume [7]. A method was developed to determine the amount of SNF remaining in solution, and therefore the amount adsorbed. It was found that at high dosage levels a substantial concentration of SNF was maintained in solution for several hours. It was further shown that the addition of silica fume to cement significantly increased the superplasticizer adsorption. However, silica fume by itself caused only slight adsorption, even using a highly alkaline solution to simulate the solution in the presence of portland cement. The increased adsorption cement mixed with silica fume was attributed to an unspecified interaction between hydrating cement and silica fume. A possible explanation for this effect is that superplasticizer is adsorbed on $\mathrm{C}-\mathrm{S}-\mathrm{H}$ that has nucleated on the silica fume surface.

Because it is widely believed that adsorption of superplasticizer occurs mainly on calcium aluminate phases, we set out in the present study, carried out while the first-named author was on sabbatical at NIST, to determine to what extent superplasticizer is adsorbed on $\mathrm{C}-\mathrm{S}-\mathrm{H}$ gel. We also set out to determine whether superplasticizer is adsorbed on the anhydrous calcium silicate surface or on $\mathrm{C}-\mathrm{S}-\mathrm{H}$ gel as it forms during hydration. The only published study we found concerning this question was a paper by costa et al. [6], who concluded that adsorption of superplasticizer on $\mathrm{C}_{3} \mathrm{~S}$ takes place on a layer of gel-like hydration product; their study was carried out in very dilute suspensions of $\mathrm{C}_{3} \mathrm{~S}$, and we thought it necessary to consider systems at the higher concentrations typical of portland cement concrete. Results from the present study will eventually be incorporated into models describing the rheological behavior of cement-water suspensions, including the role of dispersants.

\section{EXPERIMENTAL APPROACH}

\subsection{Materials}

Superplasticizer adsorption was measured on aqueous suspensions of several materials: portland cement, tricalcium silicate $\left(\mathrm{C}_{3} \mathrm{~S}\right)$, silica fume, wollastonite, and calcium silicate hydrate gel $(\mathrm{C}-\mathrm{S}-\mathrm{H})$. 
The cement and silica fume were the same materials used by Diamond and struble [7]. The cement was an ordinary ASTM Type I portland cement. Silica fume consists of submicrometer spheres of glassy silica, which does not itself react with water, but reacts with $\mathrm{CH}$ in water to form $\mathrm{C}-\mathrm{S}-\mathrm{H}$ gel. The silica fume was found to consist largely of particles in the $0.2 \mu \mathrm{m}$ to $0.4 \mu \mathrm{m}$ range.

Tricalcium silicate $\left(C_{3} S\right)$, the principal constituent of portland cement, reacts with water to form $\mathrm{C}-\mathrm{S}-\mathrm{H}$ and $\mathrm{CH}$. For this study, a monoclinic, laboratory-synthesized $\mathrm{C}_{3} \mathrm{~s}^{2}$ with a specific surface area (Blaine) of $0.19 \mathrm{~m}^{2} / \mathrm{g}$ was used.

Wollastonite, monocalcium silicate (CS), is a naturally occurring calcium silicate that does not react with water. For this study, wollastonite ${ }^{3}$ was ground in a ring-and-puck mill then jet-milled to produce a high surface area to increase the potential adsorption.

The $\mathrm{C}-\mathrm{S}-\mathrm{H}$ was synthesized from a mixture of $\mathrm{CH}$, silica, and water in a molar ratio of 1.5:1.0:0.6. Reagent-grade calcium hydroxide and distilled and deionized water were used. The silica ${ }^{4}$ was in the form of $2 \mu \mathrm{m}$ particles, with a nominal purity of 99 percent and a specific surface area of $225 \mathrm{~m}^{2} / \mathrm{g}$. The mixture was ground for 5 days using an alumina ball mill maintained in a nitrogen atmosphere. It was then dried in a vacuum oven for $16 \mathrm{hrs}$ at $50^{\circ} \mathrm{C}$. It was examined using $\mathrm{x}-\mathrm{ray}$ diffraction; its diffraction pattern (Fig. 2) matched closely the pattern for tobermorite . The pattern shows no evidence of carbonate formation. On examination using a scanning electron microscope (SEM) (Fig. 3), most particles were seen to be rounded, approximately $1 \mu \mathrm{m}$ to $2 \mu \mathrm{m}$ in diameter, with a slightly foiled surface texture.

\footnotetext{
${ }^{2}$ Designated B-400, obtained from the Construction Technologies Laboratories, Skokie IL.
}

${ }^{3}$ Obtained from Wards Natural Science Establishment, Rochester NY. This and other trade names and company products are identified throughout this report to specify adequately the experimental procedures. In no case does such identification imply recommendation or endorsement by NIST, nor does it imply that the products are necessarily the best available for the purpose.

${ }^{4}$ Sylox 2, obtained from W.R. Grace, Chemical Division, Baltimore MD.

${ }^{5}$ Pattern 19-1364 in the Powder Diffraction File of the Joint Committee on Powder Diffraction Standards. 

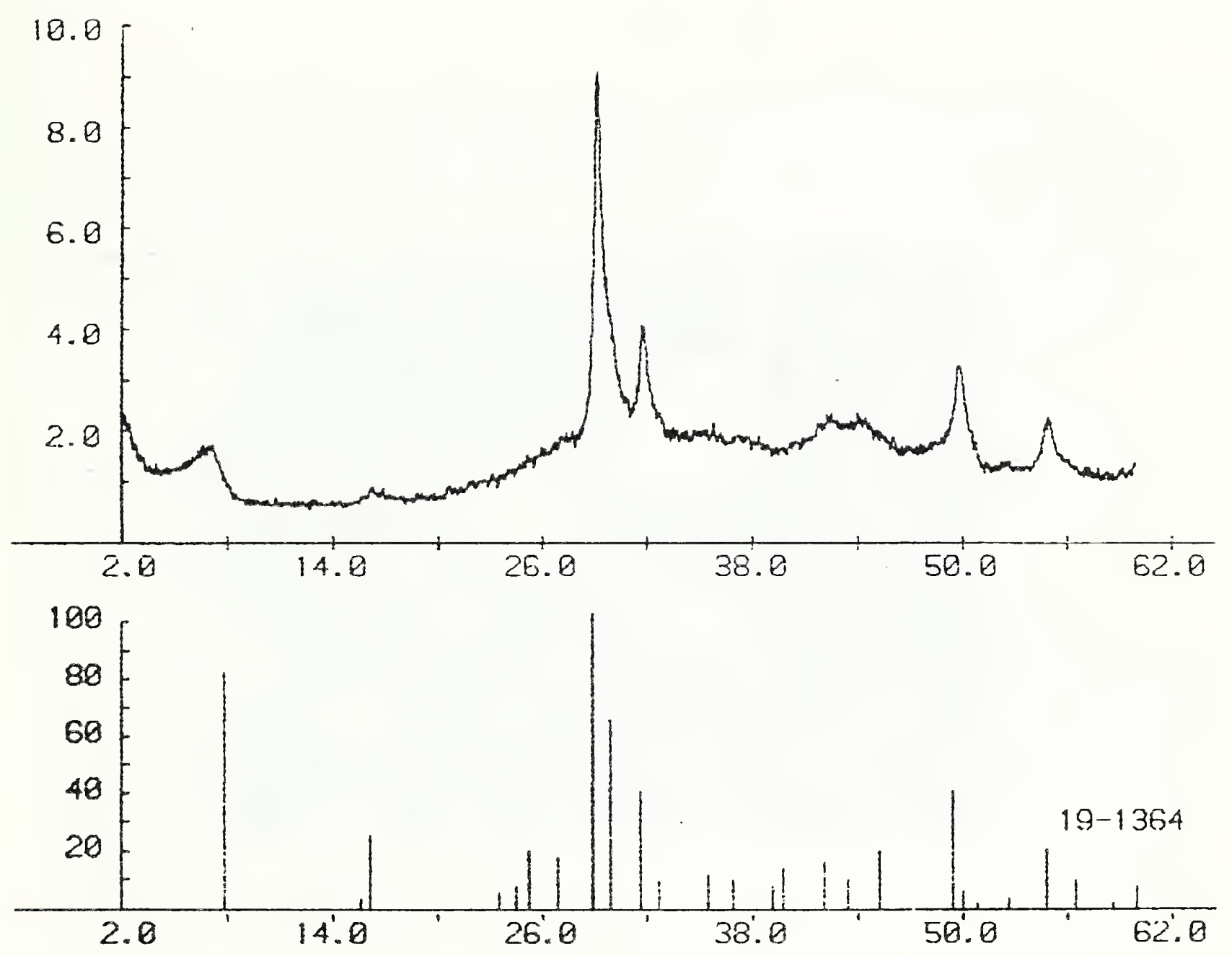

Figure 2. X-ray diffraction pattern of synthesized C-S-H (top) with JCPDS data for tobermorite (19-1364) (bottom) for comparison; the abscissa scale is ${ }^{\circ}(2 \theta)$ using $\mathrm{Cu} \mathrm{K} \alpha$ radiation. 


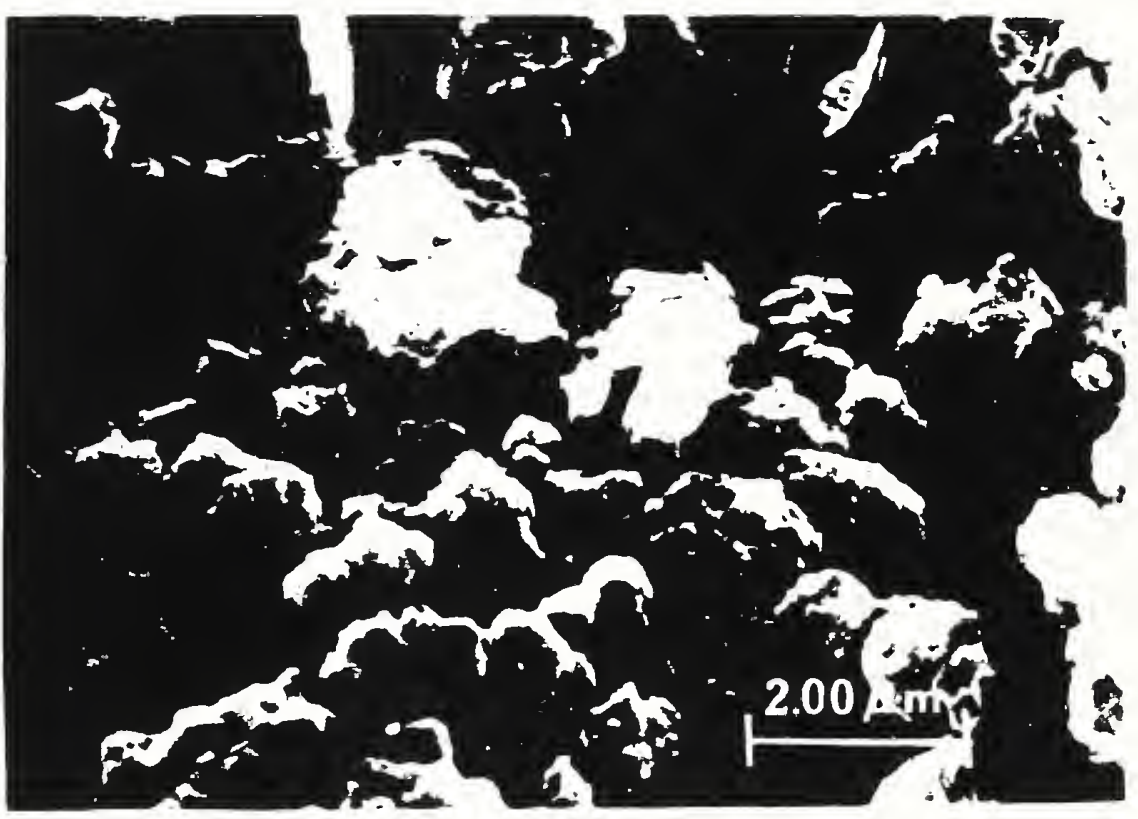

Figure 3. Scanning electron micrograph of synthesized C-S-H. 
The surface area of each solid phase was measured using a single-point BET (nitrogen adsorption) apparatus. The results are presented in Table 1.

Both superplasticizers were used in previous studies in our laboratory. The $\mathrm{SNF}^{6}$ was used by Diamond and struble [7], and the $\mathrm{SMF}^{7}$ was used by Brown [8].

\subsection{Procedures}

The pastes were mixed using a water-to-solid ratio of 0.5 by mass. Superplasticizer was dissolved in the water prior to mixing, using an amount equal to 2 percent by mass of the solid phase (same as the highest dosage of superplasticizer described by Diamond and Struble [7]). In general, $200 \mathrm{~g}$ solids and $100 \mathrm{ml}$ aqueous solution of superplasticizer were mixed. Mixing was carried out by hand. The suspensions were allowed to hydrate for a specified period of time, then filtered using pressurized nitrogen gas at $140 \mathrm{KPa}(20 \mathrm{psi})$ and membrane filters with a nominal channel diameter of $0.45 \mu \mathrm{m}$.

The concentrations of superplasticizer in solution were measured using a Perkin-Elmer 552 Ultraviolet (UV)-Visible Spectrophotometer. Before analysis, $1 \mathrm{ml}$ of each filtrate was diluted 1:1000 using distilled water. During the dilution procedure, $5 \mathrm{ml}$ of $0.1 \mathrm{M} \mathrm{HCl}$ (reagent grade) was added to prevent any possible precipitation (none was observed).

For SNF, the absorption peak at $290 \mathrm{~nm}$ was used. As discussed by Diamond and struble [7], the weak absorption peak at $290 \mathrm{~nm}$ has an advantage over the much more intense peak at $228 \mathrm{~nm}$ for determining SNF in solution. Using the more intense peak at $228 \mathrm{~nm}$ requires correcting the intensity for the proportion of residual monomer in each solution analyzed. The weaker peak at $290 \mathrm{~nm}$ exhibits the same extinction coefficient for all naphthalene sulfonate species, so no correction is necessary. In the present study, a new calibration curve for SNF solutions of varying concentrations was obtained, and an extinction coefficient value of $2.18 \mathrm{l} / \mathrm{g}-\mathrm{cm}$ calculated. This compares well with the value of 2.26 reported by Diamond and Struble [7] and the value of 2.08 reported by Burk et al. [9]. Below SNF concentrations of $-12 \mathrm{mg} / \mathrm{l}$, the wavelength of maximum absorption in the $290 \mathrm{~nm}$ region did increase slightly. This effect is shown in Fig. 4 .

\footnotetext{
${ }^{6}$ Obtained from Dr. James Gaidis, W.R. Grace \& Co., Columbia MD. 'Melment, F10, SKW Chemical Inc., Marietta GA.
} 
Table 1

Surface Area Measurements ${ }^{a}$

Material

Specific Surface Area $\left(\mathrm{m}^{2} / \mathrm{g}\right)$

portland cement

1.3

$\mathrm{C}_{3} \mathrm{~S}$

0.72

wollastonite

0.3

silica fume

18.6

$\mathrm{C}-\mathrm{S}-\mathrm{H}$

79.1

${ }^{a}$ Measured using a single-point BET (nitrogen adsorption) apparatus. Each value is the average of 3 determinations. 


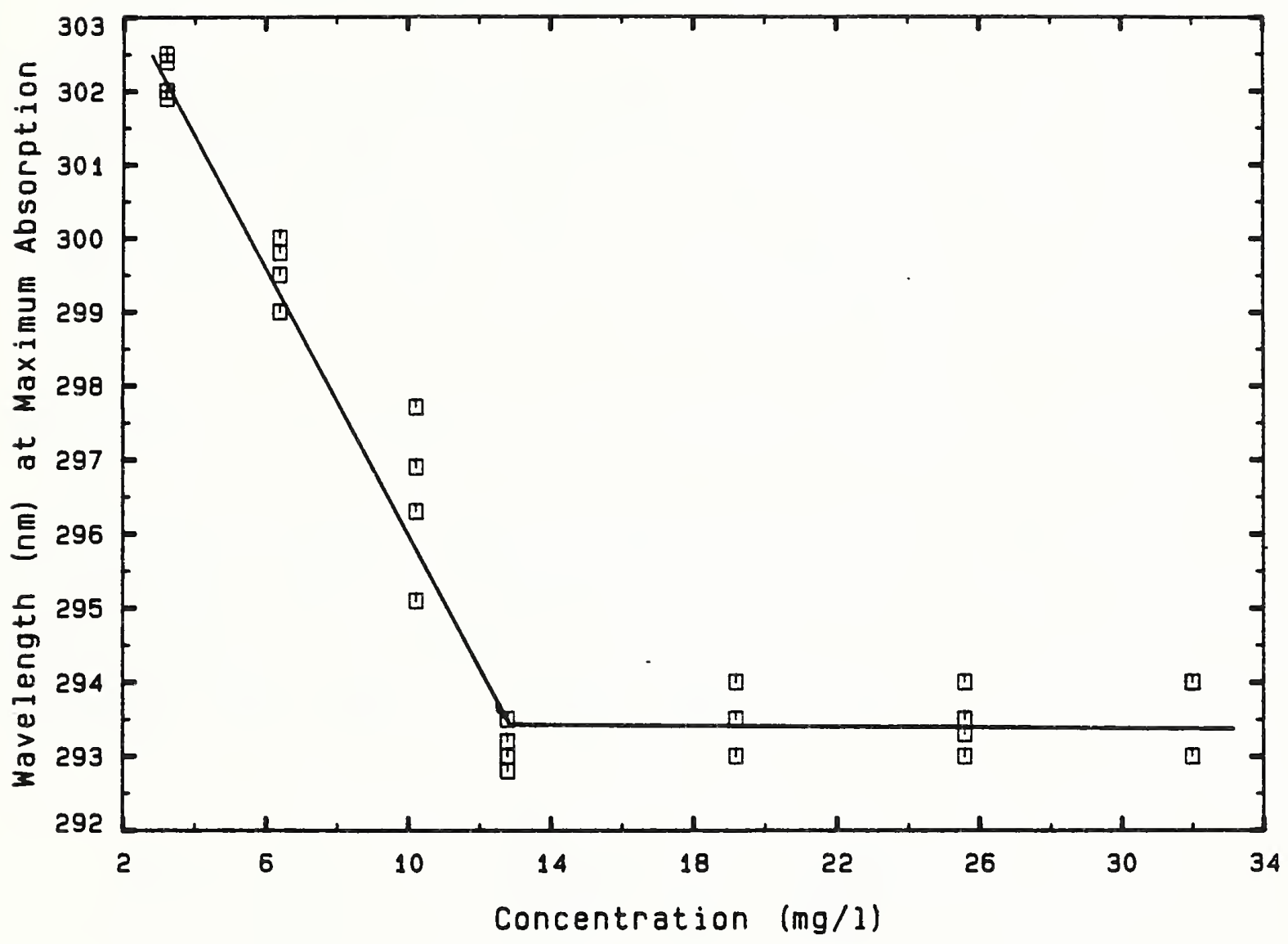

Figure 4. Wavelength of maximum UV absorption versus concentration in aqueous solution for sulfonated naphthalene formaldehyde. 
For SMF, the wavelength of maximum absorption was found to be $217 \mathrm{~nm}$. This wavelength did not vary with concentration (Fig. 5).

\section{RESULTS AND DISCUSSION}

Figures 6 and 7 show adsorption by portland cement, at a water-to-cement ratio 0.5 , with 2 percent SNF by mass of cement. The results are presented in the form of the amount of superplasticizer adsorbed on the solid material versus hydration time (Fig. 6), or in the form of concentration of superplasticizer remaining in solution versus hydration time (Fig. 7).

Appreciable adsorption of the superplasticizer occurred by the first measurement ( $5 \mathrm{~min}$ ) and the rate of adsorption appears to be most rapid during the initial period. The rate of adsorption decreased to zero by -40 min hydration time, and the level of adsorption remained constant at $10.4 \mathrm{mg} / \mathrm{g}$ cement during the remainder of the experiment $(\sim 4 \mathrm{hr})$. The SNF in solution decreased from its initial concentration of $40 \mathrm{~g} / \mathrm{l}$ to a level of $19 \mathrm{~g} / \mathrm{l}$ after $40 \mathrm{~min}$ (Fig. 7).

Results from the previous study [7] are also included in Figs. 6 and 7. Results from the two studies agree well, though not quite precisely.

The adsorption of SMF on cement-water suspensions (Fig. 8) followed a similar pattern, though the adsorption of SMF did not level off as quickly as did the adsorption of SNF. Adsorption of SMF appeared to level off by $-2 \mathrm{hr}$ (compared to $-40 \mathrm{~min}$ for SNF), at which time the amount of adsorbed SMF was $9.4 \mathrm{mg}$ per $\mathrm{g}$ cement. The adsorption of SMF on cement plus silica fume (Fig. 8) was 9.7 mg per $g$ solid, slightly higher than the adsorption of SMF on cement.

The effect of silica fume on adsorption of SMF was similar, though lower in magnitude, to the effect of silica fume on adsorption of SNF reported previously [7]. In the previous study, addition of silica fume increased the amount of SNF adsorbed from $10 \mathrm{mg}$ per $\mathrm{g}$ cement to $13 \mathrm{mg}$ per $\mathrm{g}$ cement plus silica fume, a 30 percent increase. In the present study, addition of silica fume increased the amount of SMF adsorbed from $9.4 \mathrm{mg}$ per $\mathrm{g}$ cement to $9.7 \mathrm{mg}$ per $\mathrm{g}$ cement plus silica fume, only a 3 percent increase. This difference appears to reflect differences between SNF and SMF.

The adsorption of SMF in $\mathrm{C}_{3}$ S-water suspensions (Fig. 8) was only slightly lower than adsorption in cement-water suspensions, and the pattern of adsorption was quite similar. The level of adsorption at 2 hours was $9.2 \mathrm{mg}$ per $g \mathrm{C}_{3} \mathrm{~S}$. 


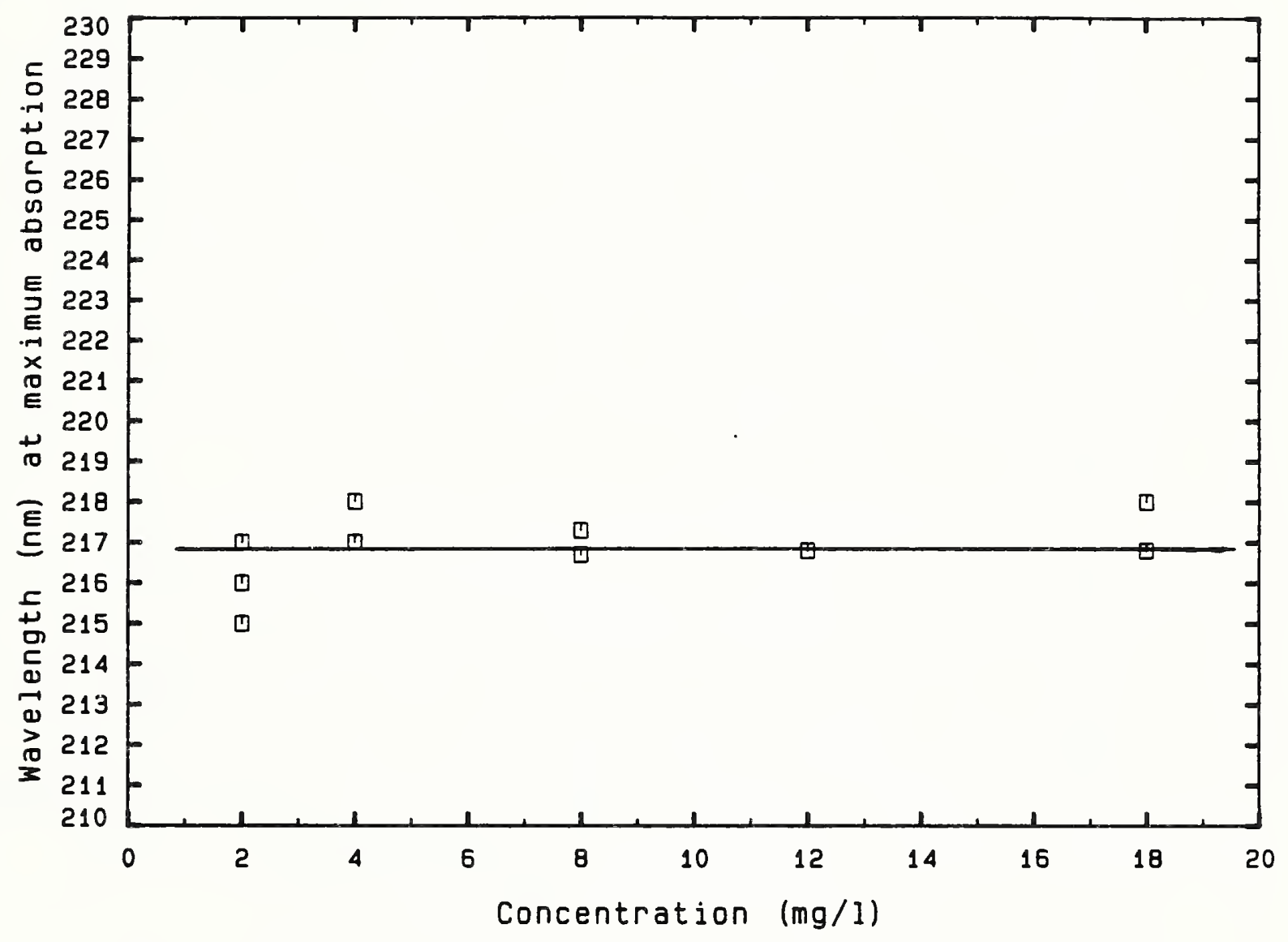

Figure 5. Wavelength of maximum UV absorption versus concentration in aqueous solution for sulfonated melamine formaldehyde. 


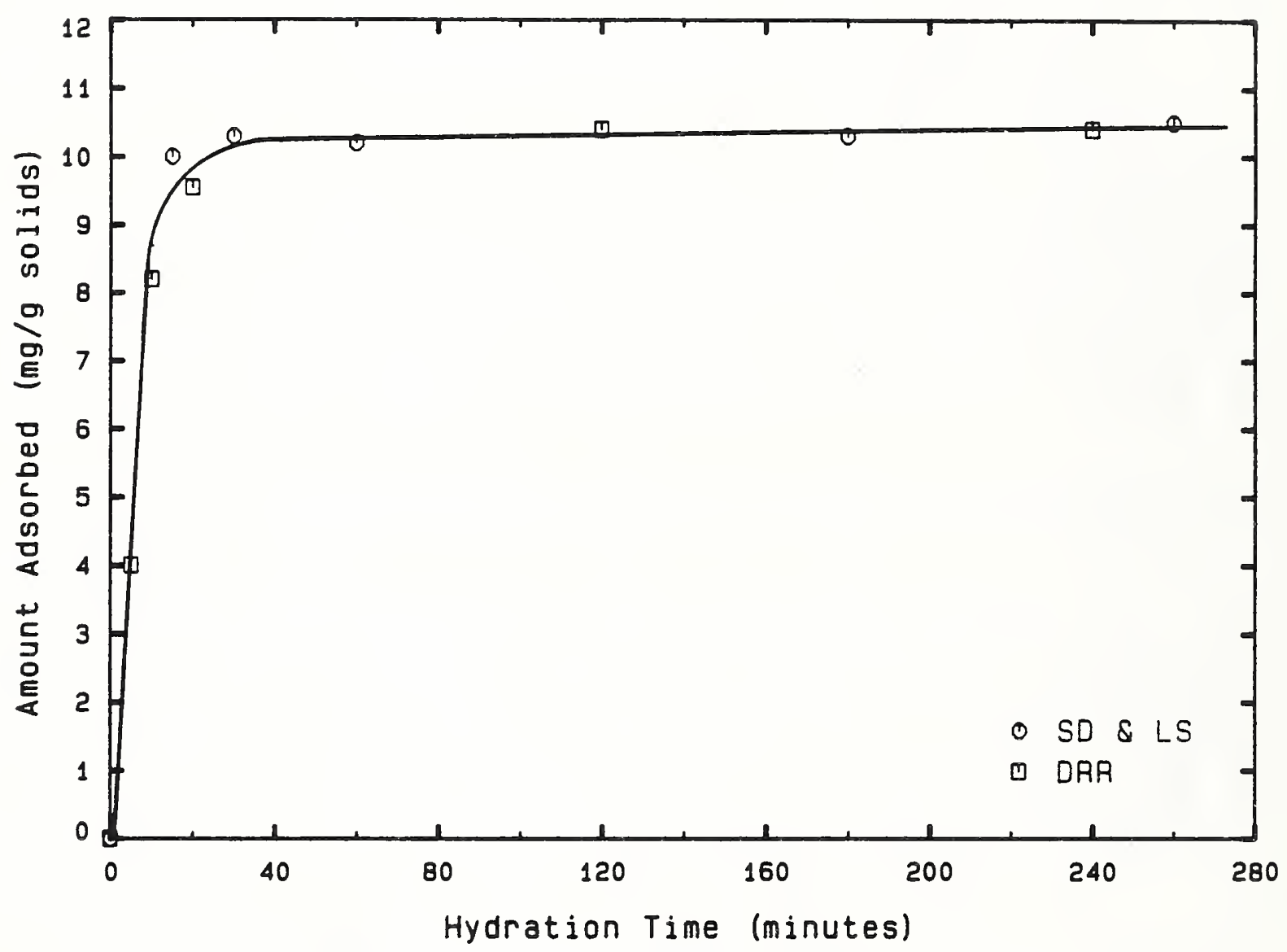

Figure 6. Adsorption of sulfonated naphthalene formaldehyde in portland cement-water suspensions, water-to-cement ratio 0.5 by mass, 2 percent sulfonated naphthalene formaldehyde by mass of cement, comparing data from the previous study [7] (labeled SD \& LS) and from the present study (labeled DRR). 


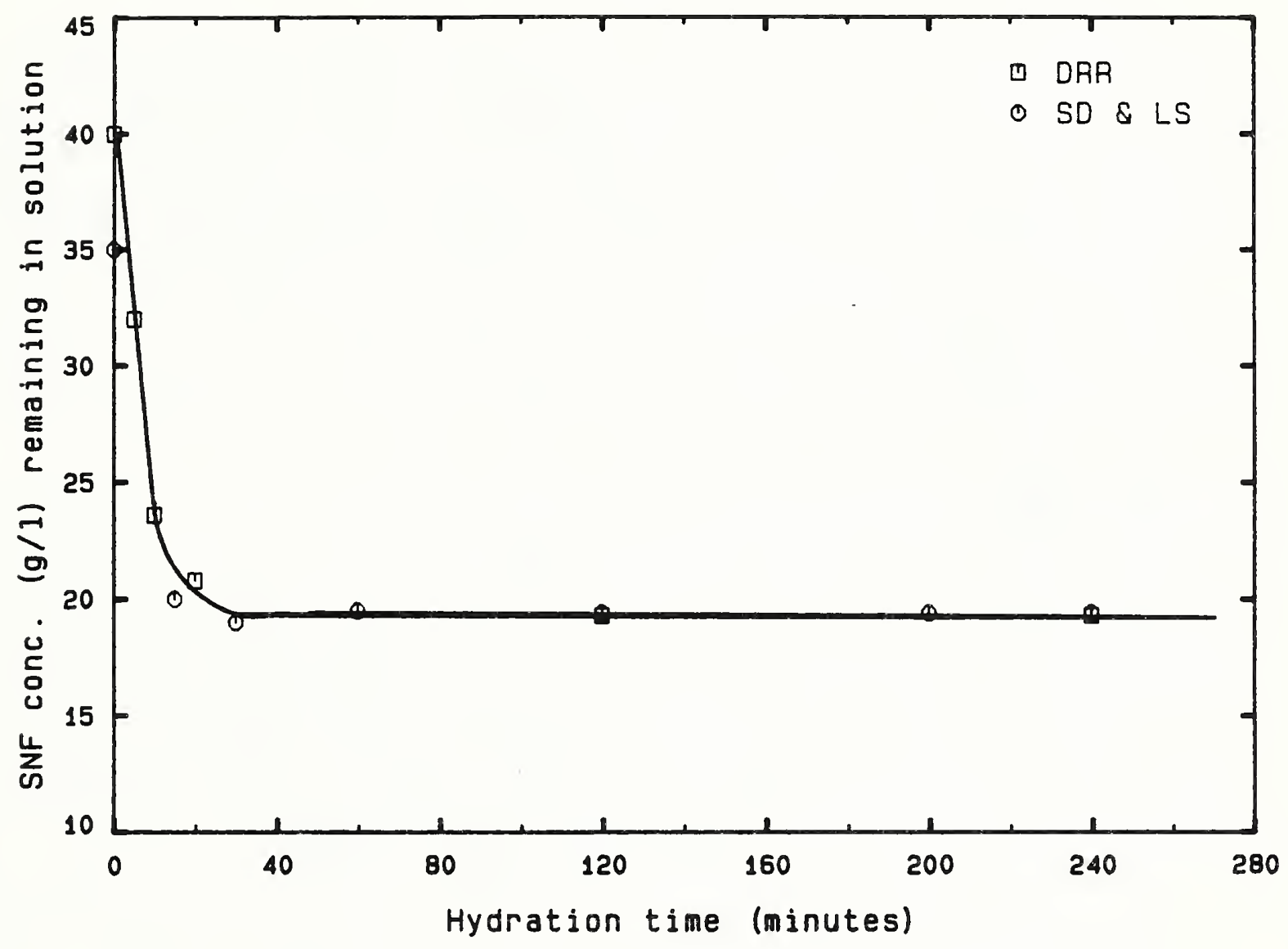

Figure 7. Concentration of sulfonated naphthalene formaldehyde remaining in aqueous solution in portland cement-water suspensions, from adsorption data in Fig. 6 . 


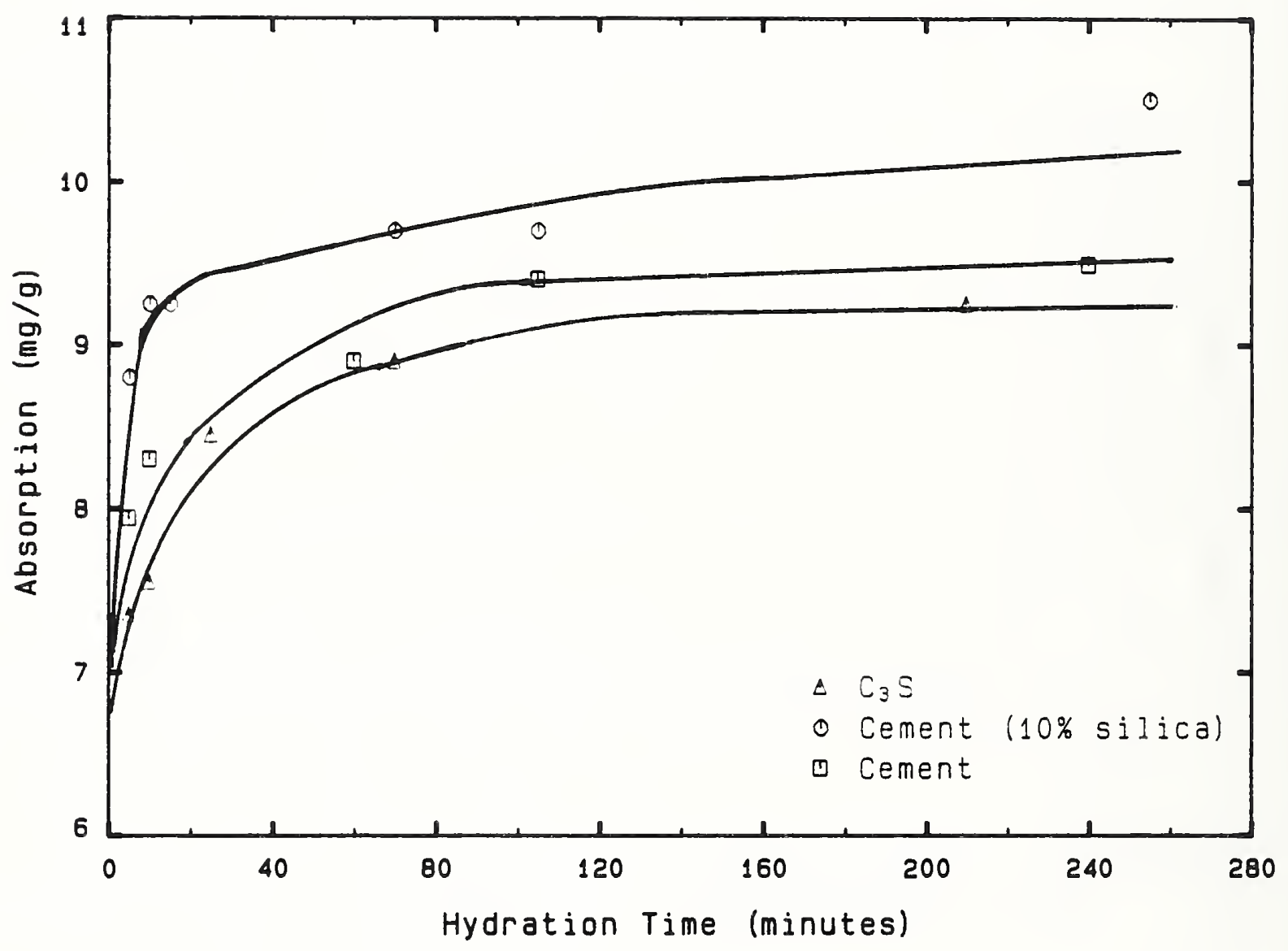

Figure 8. Adsorption of sulfonated melamine formaldehyde in various aqueous suspensions, water-to-solids ratio 0.5 by mass, 2 percent sulfonated melamine formaldehyde by mass of solid. 
No uptake of either SNF or SMF by CS or CS plus silica fume was detected at ages up to $7 \mathrm{hr}$. The limits of detection of the spectrophotometer are conservatively estimated to be $0.4 \mathrm{mg} / 1$ for SNF and $0.1 \mathrm{mg} / 1$ for SMF, corresponding to an adsorption on the CS solids of less than $0.05 \mathrm{mg}$ per $\mathrm{g}$ solid. This is negligible compared to the adsorption levels in Figs. 6 and 8 .

Adsorption of SNF on synthesized $\mathrm{C}-\mathrm{S}-\mathrm{H}$ is plotted in Fig. 9. In this case, a water-to-solids ratio of 1.5 was required to provide a workable mixture. The level of adsorption was very high, $37 \mathrm{mg}$ per $\mathrm{g}$ solid, and did not change throughout the 4-hr period.

The levels of superplasticizer adsorbed may be estimated relative to the surface area using the measured specific surface areas listed in Table 1. With portland cement, adsorption of SNF was $7.7 \mathrm{mg}$ per $\mathrm{m}^{2}$ cement and adsorption of SMF was $7.1 \mathrm{mg}$ per $\mathrm{m}^{2}$ cement. With cement plus silica fume, adsorption of SMF was 3.2 $\mathrm{mg}$ per $\mathrm{m}^{2}$ solid. The previously reported [7] adsorption levels on cement plus silica fume are equivalent to $4.3 \mathrm{mg} \mathrm{SNF}$ per $\mathrm{m}^{2}$ solid. The adsorption of SMF by $C_{3} S$ was $12.5 \mathrm{mg}$ per $\mathrm{m}^{2} \mathrm{C}_{3} \mathrm{~S}$, higher than the adsorption of SMF cement $\left(7.1 \mathrm{mg}\right.$ per $\mathrm{m}^{2}$ of cement). However, the adsorption of SNF by $\mathrm{C}-\mathrm{S}-\mathrm{H}$ was $0.5 \mathrm{mg}$ per $\mathrm{m}^{2}$ solid, very much lower than the adsorption of SNF by either $\mathrm{C}_{3} \mathrm{~S}$ or cement.

These results may be explored further to determine whether adsorption by $\mathrm{C}_{3} \mathrm{~S}$ is taking place on the anhydrous surface or on a layer of $\mathrm{C}-\mathrm{S}-\mathrm{H}$. No adsorption of superplasticizer occurred on CS or silica fume (each nonreactive to water) suggesting that formation of $\mathrm{C}-\mathrm{S}-\mathrm{H}$ is necessary for adsorption. Furthermore, as noted above, the adsorption per unit surface by $\mathrm{C}-\mathrm{S}-\mathrm{H}$ was much lower than the adsorption by $\mathrm{C}_{3} \mathrm{~S}$. This difference in adsorption may occur because little of the internal surface of $\mathrm{C}-\mathrm{S}-\mathrm{H}$ participates in the adsorption. If that is a correct explanation, then the adsorption by $\mathrm{C}-\mathrm{S}-\mathrm{H}$ would take place only on the surface of the large $(1.5 \mu \mathrm{m})$ particles observed in the SEM micrograph (Fig. 3). In that case, the surface available for adsorption would be roughly the outer surface of $1.5 \mu \mathrm{m}$ particles, with a surface of $7.07(\mu \mathrm{m})^{2}$ and a volume of 1.18 $(\mu \mathrm{m})^{3}$; using a density of $2.60 \mathrm{~g} / \mathrm{cm}^{3}$ for $\mathrm{C}_{3} \mathrm{~S}$ [11], this is equivalent to a surface area of $2.30 \mathrm{~m}^{2} / \mathrm{g}$. Based on this estimated surface area, the measured adsorption by $\mathrm{C}-\mathrm{S}-\mathrm{H}$ (37 $\mathrm{mg} / \mathrm{g}$ ) is $16 \mathrm{mg} / \mathrm{m}^{2}$, not very different from the adsorption by $\mathrm{C}_{3} \mathrm{~S}$ of $12.5 \mathrm{mg} / \mathrm{m}^{2}$. Thus it appears reasonable that what appears to adsorption by $\mathrm{C}_{3} \mathrm{~s}$ or cement is actually adsorption by the outer surface of a layer of $\mathrm{C}-\mathrm{S}-\mathrm{H}$ on the $\mathrm{C}_{3} \mathrm{~S}$. A similar conclusion was drawn by costa et al. [6] from studies of the adsorption of superplasticizer on $\mathrm{C}_{3} \mathrm{~s}$ using a nonaqueous solvent. 


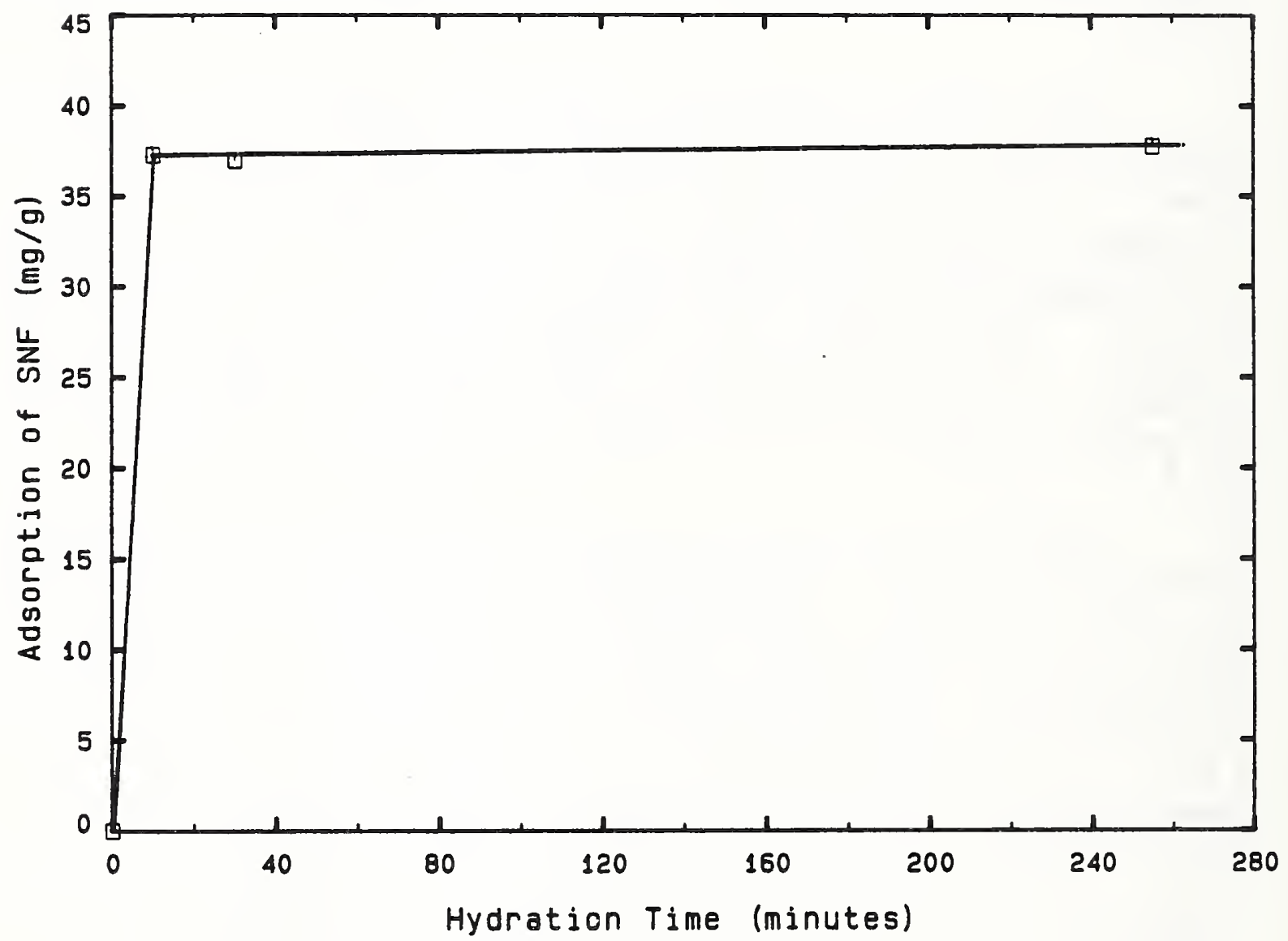

Figure 9. Adsorption of sulfonated naphthalene formaldehyde in $\mathrm{C}-\mathrm{S}-\mathrm{H}$ suspension, water-to-solids ratio 1.5 by mass, 2 percent sulfonated naphthalene formaldehyde by mass of solid. 
There is one remaining discrepancy in our experimental results. If the silica fume provides nucleation sites for $\mathrm{C}-\mathrm{S}-\mathrm{H}$ and silica fume coated with $\mathrm{C}-\mathrm{S}-\mathrm{H}$ adsorbs superplasticizer, one would expect a similar adsorption level, relative to surface area, between cement and cement plus silica fume. However, as noted above, on this basis the adsorption by cement was roughly half the adsorption by cement plus silica fume. It appears that the silica fume is covered with $\mathrm{C}-\mathrm{S}-\mathrm{H}$ to a much lesser extent than the cement grains during this time period.

\section{CONCLUSIONS}

been drawn:

Based on the study described, the following conclusions have

1. In a cement-water suspension, the addition of silica fume enhances adsorption of SMF, though not to the extent observed previously for SNF.

2. No measurable adsorption of superplasticizer from aqueous solution occurs on wollastonite.

3. The adsorption of superplasticizer was nearly as great on $C_{3} S$ as on cement when based on mass, and greater on $C_{3} S$ than on cement when based on surface area.

4. There was considerable adsorption of SNF on $\mathrm{C}-\mathrm{S}-\mathrm{H}$; based on mass, the uptake of SNF on $\mathrm{C}-\mathrm{S}-\mathrm{H}$ was much greater than its adsorption on cement.

5. It appears that superplasticizer is not significantly adsorbed on the surface of anhydrous silica or anhydrous calcium silicates, but is adsorbed substantially by $\mathrm{C}-\mathrm{S}-\mathrm{H}$ gel. Adsorption by a layer of $\mathrm{C}-\mathrm{S}-\mathrm{H}$ gel on the surface of grains may account for most or all of the adsorption on cement.

\section{RECOMMENDED FUTURE WORK}

Based on this work, additional studies are recommended to improve our understanding of the adsorption of superplasticizer by portland cement:

1. To better understand the processes by which superplasticizer is adsorbed by cement from aqueous solution and to model these processes, the adsorption studies should be extended to other cements, especially to cements with a range of $\mathrm{C}_{3} \mathrm{~A}$ contents. 
2. For more definitive conclusions regarding the role of $\mathrm{C}-\mathrm{S}-\mathrm{H}$ gel on the surface of cement grains in superplasticizer adsorption, adsorption studies should be combined with ESCA studies to determine chemical composition of the grain surfaces. Similarly, the adsorption should be related to the degree of hydration using isothermal calorimetry.

3. Adsorption isotherms should be measured in order to estimate the proportion of surface area covered by adsorbed superplasticizer and thereby better model the adsorption process.

\section{ACKNOWLEDGEMENTS}

The authors acknowledge technical support provided by $w$. Roberts and P. Stutzman at NIST, and suggestions and materials provided by J. Gaidis and E. Gartner of W.R. Grace \& Co., Columbia MD. 
REFERENCES

1. V.S. Ramachandran and V.M. Malhotra, Superplasticizers, Chapter 4 in: Concrete Admixtures Handbook, edited by V.S. Ramachandran, Noyes Publication, Park Ridge NJ, 1984.

2. G.H. Tattersall and P.F.G. Banfill, The Rheology of Fresh Concrete, Pitman Advanced Publishing Program, Boston, 1983.

3. D.M. Roy and M. Daimon, Effects of admixtures upon electrokinetic phenomena during hydration of $C_{3} S, C_{3} A$ and portland cement, in: 7th International congress on the Chemistry of Cement, Paris, Vol. IV, 524-528, 1980.

4. M. Daimon and D.M. Roy, Rheological properties of mixes, II zeta potential and preliminary viscosity studies, Cement and Concrete Research, 9 103-110, 1979.

5. P.J. Andersen, D.M. Roy, and J.M. Gaidis, The effect of superplasticizer molecular weight on its adsorption on, and dispersion of, cement, Cement and Concrete Research, 18 980986,1988 .

6. U. Costa, F. Massazza, and A. Barrilà, Adsorption of superplasticizers on $\mathrm{C}_{3} \mathrm{~S}$ : changes in zeta potential and rheology of pastes, II Cemento, $\underline{4} 323-336,1982$.

7. S. Diamond and L.J. Struble, Interaction between naphthalene sulfonate and silica fume in portland cement pastes, in: Bonding in Cementitious Composites, Materials Research Society Symposium Proceedings, Vol. 114, 117-126, 1988.

8. M. Brown, Investigation of strength-producing mechanisms in selected pastes and mortars, PhD thesis, clemson University, 100 pages, 1988 .

9. A.A. Burk, Jr., J.M. Gaidis, and A.M. Rosenberg, Adsorption of naphthalene based superplasticizers on different cements, $21 \mathrm{pp}$. (preprint of a paper presented at the 2nd International conference on superplasticizers in concrete, ottawa, 1981, but not published in the proceedings).

10. J.F. Young and W. Hansen, Volume relationships for $\mathrm{C}-\mathrm{S}-\mathrm{H}$ formation based on hydration shoichiometries, in: Microstructural Development During Hydration of Cement, Materials Research Society symposium Proceedings, Vol. 85, 313-322, 1987 . 
NIST-114A

(REV. 3-89)
U.S. DEPARTMENT OF COMMERCE NATIONAL INSTITUTE OF STANDARDS AND TECHNOLOGY

\section{BIBLIOGRAPHIC DATA SHEET}

1. PUBLCATION OR REPONT NUMBER

NISTIR 89-4172

2. PERFORMINO ORGANIZATION REPORT NUMBER

3. PUEUCATION DATE

SEPTEMBER 1989

4. TITLE AND SUBTTITE

Adsorption of High-Range Water-Reducing Agents on Selected Portland Cement Phases and Related Materials

5. AUTHON(S)

David R. Rossington and Leslie J. Struble

6. PERFOAMING OROANIZATION (IF JOINT OR OTHER THAN MIST, SEE INSTRUCTIONS)

U.S. DEPARTMENT OF COMMERCE

MATIONAL INSTTTUTE OF STANDARDS AND TECHNOLOQY

CATTHEASEURO, MD 20890

7. CONTRACT/ORANT MUMEER

8. TYPE OF REPORT AND PEAIOD COVERED

9. SPONSORING ORQANIZATION NAME AND COMPLETE ADDRESS (STREET, CTY, STATE, ZPP)

DOCUMEMT DESCRIBES A COMPUTER PROGRAM; SF-185, FIPS SOFTWARE SUMMARY, IS ATTACHED.

11. AESTRACT (A 200-WORD OR LESS FACTUAL SUMMARY OF MOST SIGMIFICANT INFOAMATION. IF DOCUMENT INCLUDES A SIONIFICANT BIQUOQRAPHY OR UTERATURE SURVEY, MENTION IT HERE.)

The quantities of high-range water-reducing agents (superplasticizer) absorbed from their aqueous solutions by portland cement, tricalcium silicate, silica fume, wollastonite, and calcium silicate hydrate gel were determined using an ultraviolet spectrophotometer. The two superplasticizers (sulfonated melamine formaldehyde and sulfonated naphthalene formaldehyde) produced generally similar results. Wollastonite, a calcium silicate that does not react with water, produced no measurable adsorption of superplasticizer. The adsorption of superplasticizer by tricalcium silicate was sinilar to the adsorption by portland cement. From these results, it appears that superplasticizer is not absorbed by anhydrous silica or anhydrous calcium silicate, but rather by calcium silicate hydrate gel. Additional studies are recommended for improving the understanding of the absorption of superplasticizer by portland cement.

12. KEY WOADS (6 TO 12 ENTRIES; ALPHABETICAL ORDEA; CAPITALIZE ONLY PAOPEA MAMES; AND SEPARATE KEY WORDS BY SEMICOLONS) adsorption; calcium silicate hydrate; cement; concrete; silicate fume; sulfonated melamine formaldehyde; sulfonated naphthalene formaldehyde; superplasticizer; tricalcium silicate; sollastonite

\section{AVALABIUTY}

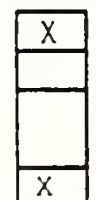

UNLMITED

FOR OFFICIAL DISTRIBUTION. DO NOT RELEASE TO NATIONAL TECHNICAL INFORMATION SERVICE (NTIS).

ORDER FROM SUPERINTENDENT OF DOCUMENTS, U.S. GOVERNMENT PRINTING OFFICE. WASHINQTON, DC 20402.

ORDEA FROM NATIONAL TECHNICAL INFORMATION SERVICE (NTIS), SPRINGFIELD, VA 22161.

14. NUMBER OF PAINTED PAGES

\section{6}

15. PRICE

$\mathrm{AO} 3$ 


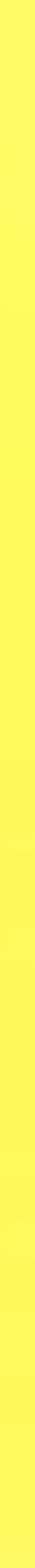


